Rev. Int. Contam. Ambie. 36 (4) 813-824, 2020

https://doi.org/10.20937/RICA.53466

\title{
RISK INDICATORS FOR AGRICULTURAL USE IN OIL-CONTAMINATED SOILS
}

Indicadores de riesgo para uso agrícola de suelos contaminados con petróleo

\section{Dinora VÁZQUEZ-LUNA ${ }^{1 *}$, Elizabeth HERNÁNDEZ-ACOSTA², Joel ZAVALA-CRUZ ${ }^{3}$, Mayra VÁZQUEZ-LUNA ${ }^{4}$ and Daniel Alejandro LARA-RODRÍGUEZ ${ }^{1}$}

${ }^{1}$ Centro de Estudios Interdisciplinarios en Agrobiodiversidad, Facultad de Ingeniería en Sistemas de Producción Agropecuaria, Universidad Veracruzana, km 220 Carretera Costera del Golfo, C. Agrícola y Ganadera, 96000 Acayucan, Veracruz, México.

${ }^{2}$ Centro de Investigación en Recursos Naturales y Medio Ambiente, Universidad Autónoma Chapingo, km 38.5 carretera federal México-Texcoco, 56230, Texcoco, Estado de México, México.

${ }^{3}$ Producción Agroalimentaria en el Trópico, Colegio de Posgraduado, km 3 Periférico Carlos A. Molina s/n, 86500 Cárdenas, Tabasco México.

${ }^{4}$ Doctorado en Ciencias Agropecuarias, Facultad de Agronomía, Universidad Veracruzana, Circuito Gonzalo Aguirre Beltrán s/n, Zona Universitaria, 91090 Xalapa-Enríquez, Ver.

*Author for correspondence: divazquez@uv.mx

(Received: November 2018; accepted: January 2020)

Key words: weathered hydrocarbon, polluted soil, agricultural land use.

\begin{abstract}
Oil activities have mainly affected the tropical zones of developing countries, and these effects have been difficult to measure due to the lack of in-situ monitoring indicators in agricultural areas. We determined the physical and chemical properties of soils sampled from four villages situated on the floodplain of the Tonalá River in Tabasco, Mexico, and we analyzed the productive characteristics and total petroleum hydrocarbon (TPH) content in each site. The aim was to assess the potential risks affecting agricultural use in areas with or without oil wells. Three indicators were developed: the productive diversity index $\left(\mathrm{PDI}_{\mathrm{x}}\right)$, the productive rate risk index $\left(\mathrm{PR}_{\mathrm{x}}\right)$, and the efficient land use index $\left(\mathrm{ELUI}_{\mathrm{x}}\right)$ for farming systems (crop plants $[\mathrm{p}]$ and animal rearing [a]). Results indicate that the main limiting factors for farming are the flooding characteristics of Gleysols, high salinity, and contamination by hydrocarbons, and that these were related to higher values of $P R_{a, p}$, which were recorded from zones with elevated density of oil facilities. High PDI $\mathrm{P}_{\mathrm{a}, \mathrm{p}}$ and $E L U I_{\mathrm{a}, \mathrm{p}}$ values were found in zones without oil facilities that had a greater production of crops and pastures and lower associated risk factors that are related to the presence of oil wells or soil contamination by TPH, but also to related secondary effects. These results allowed a comparison of potential risk assessment in areas with similar ecosystems, differentiating the diversity and the efficiency of productive land use related to polluted zones.
\end{abstract}

Palabras clave: hidrocarburo intemperizado, suelo contaminado, uso de la tierra agrícola. 


\section{RESUMEN}

Las actividades petroleras han afectado principalmente las zonas tropicales en países en desarrollo, efectos que ha sido difícil medir debido a la falta de indicadores de monitoreo in-situ en áreas agrícolas. Se determinaron las propiedades físicas y químicas de los suelos de cuatro comunidades situadas en la llanura aluvial del río Tonalá en Tabasco, México, y se analizaron las características productivas y el contenido total de hidrocarburos de petróleo (HTP) en cada sitio. El objetivo fue evaluar los riesgos potenciales para el uso agrícola en áreas con o sin pozos petroleros. Se desarrollaron tres indicadores: el índice de diversidad productiva $\left(\operatorname{IDP}_{\mathrm{x}}\right)$, el índice de riesgo productivo $\left(\mathrm{RP}_{\mathrm{x}}\right)$ y el índice de uso eficiente del suelo $\left(\mathrm{IUES}_{\mathrm{x}}\right)$ para los sistemas agrícolas (plantas de cultivo [p] y cría de animales [a]). Los resultados indicaron que los principales factores limitantes para la agricultura son las características de inundación de los Gleysoles, la alta salinidad y la contaminación por hidrocarburos. Éstos fueron correlacionados con valores más altos de $\mathrm{RP}_{\mathrm{a}, \mathrm{p}} \mathrm{y}$ con altas densidades de instalaciones petroleras. Se encontraron valores altos de IDP $_{a, p}$ y IUES $\mathrm{IU}_{\mathrm{a}, \mathrm{p}}$ en zonas sin instalaciones petroleras, debido a que tenían mayor producción de cultivos y pasturas, y menores factores de riesgo asociados con la presencia de pozos petroleros o con la contaminación del suelo por HTP. Estos resultados permitieron una comparación de la evaluación de riesgos potenciales en áreas con ecosistemas similares, diferenciando la diversidad y la eficiencia del uso productivo de la tierra relacionado con zonas contaminadas.

\section{INTRODUCTION}

The dependency of global economy on oil has created severe environmental problems (Hall et al. 2003). In Mexico, oil activities have mainly affected the tropical areas in the south-east of the country. This pollution has led to a decline in soil sustainability (Rodrigues et al. 2009) due to the toxic effects, which decrease the ability of soil to support living organisms, disrupt biogeochemical cycles (Labud et al. 2007), negatively impact ecosystems and alter fertility (Adams et al. 2008), thereby reducing the soil quality (Fernández et al. 2006) and disturbing the agricultural potential (Zavala-Cruz et al. 2005).

There are many studies and ex-situ assays that indicate the risk factors of the total petroleum hydrocarbon content (TPH) by assessing plants, earthworms (Cuevas-Díaz et al. 2017), microorganisms, ecosystems soil (Shen et al. 2016) and food production (Yan et al. 2015). There are not indicators to conduct a simple in-situ assessment of risk factors based on analyzing agroecosystems in oil-contaminated zones. Such studies, with the cooperation of farmers, could aid in the assessment of risk factors influencing agricultural use in countries that currently lack standards and regulations because hydrocarbon-contaminated zones require focus beyond the contaminants for regulatory decision making (Thavamani et al. 2015).

The aim of this study was to analyze the potential risk affecting agricultural use in areas with or without oil wells by evaluating the physical and chemical properties of soils, the diversity of agroecosystems and by characterizing the productive use of the study zones.

\section{MATERIALS AND METHODS}

Most soils affected by hydrocarbons in the southeast of Mexico are in mangrove ecosystems and in lowland areas that are subjected to frequent flooding. We selected four areas situated on the floodplain of the Tonalá River, with a warm humid climate and abundant rainfall in summer, annual average temperature of $26^{\circ} \mathrm{C}$, annual rainfall of 2000-2500 $\mathrm{mm}$, and one soil reported as Mollic Gleysol (RiveraCruz and Trujillo-Narcia 2004). Sampling was conducted in the towns of José N. Rovirosa $(-94.04928$, 18.09048), Paraíso (-94.04444, 18.06757), Ceiba $(-4.069211,18.042042)$ and Francisco Trujillo Gurría $(-94.067704,17.972264)$, which have differing densities of oil wells. These communities are located south of La Venta, at distances of 0.5, 2.5, 7, and 12 $\mathrm{km}$ from the petrochemical facilities, respectively. The first zone (Rovirosa) included oilfields and a petrochemical facility and was the site of an oil spill during the past 30 years. The second and third zones (Paraíso and Ceiba, respectively) were located between the oil wells of La Venta and Blasillo river. The last zone (in Gurría), had no petroleum installations. The densities of oil wells over $100 \mathrm{~m}^{2}$ were: Rovirosa, 14; Paraíso, 7; Ceiba, 1; and Gurría, 0 (Fig. 1). 


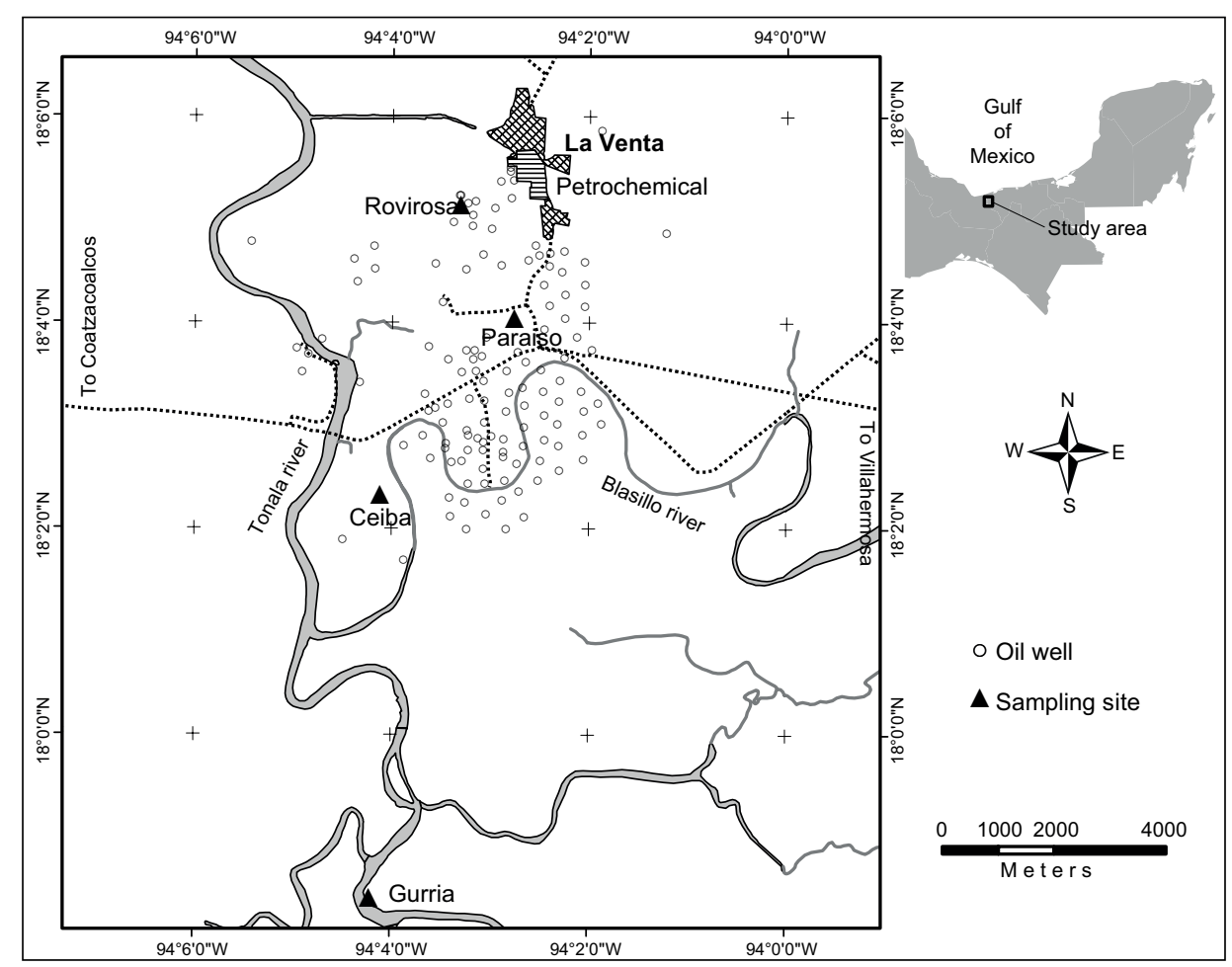

Fig. 1. Location of the study area.

\section{Agroecosystems and productive use characteri- zations}

The botanical identification was made in the herbarium of the Colegio de Postgraduados, Campus Tabasco. Agroecosystems and productive use characterizations were performed at $75 \%$ of the production farms through field visits (transects) and interviews with farmers. On each farm, we recorded in situ data that corresponded to the type of ecosystems, the predominant plant species, and the use and production systems (plant species, crops, animal husbandry, and fishing).

\section{Risk analysis of limiting factors}

Soil was sampled and fertility parameters were measured through methods based on the Official Mexican Standard NOM-021-RECNAT-2000 (SEMARNAT 2002): $\mathrm{pH}$ (measured in a 1:2 soil to water ratio); electrical conductivity (EC); organic matter (OM), by the method of Walkley and Black; cation exchange capacity (CEC), texture by the Boyoucos hydrometer method; inorganic nitrogen $(\mathrm{N})$; and exchangeable cations ( $\mathrm{Ca}, \mathrm{Mg}$ and $\mathrm{K}$ ), extracted with $1 \mathrm{~N}$ ammonium acetate $(\mathrm{pH} 7.0)$ in a 1:20 ratio and phosphorus $(\mathrm{P})$.

Sampling to quantify hydrocarbons in soil was based on NOM-138-SEMARNAT/SS-2003
(SEMARNAT 2005), for both sets of samples, i.e. soil at the surface and soil at a depth of up to $30 \mathrm{~cm}$. Composite samples were taken from each site (for a total of 180 subsamples in a zigzag sampling pattern), taking into consideration the homogeneity of natural factors. The analysis for TPH was performed in the Environmental Control laboratory of the Benemérita Universidad Autónoma de Puebla (CICM-BUAP), where TPH concentration was measured by EPA method 418.1 (EPA 1986), using an FTIR Tensor 20 spectrophotometer, Bruker brand. The sample was run from 4000 to $400 \mathrm{~cm}^{-1}$. The standard used was Altech, 418.1 and the peak area was measured to $2800 \mathrm{~cm}^{-1}$.

\section{Indices of potential risk assessment}

After characterizing the production and analyzing the soil, we identified risk factors using reports of some studies (Teng et al. 2014). We created the following indicators: the productive diversity index $\left(\mathrm{PDI}_{\mathrm{x}}\right)$, the productive rate risk $\left(\mathrm{PR}_{\mathrm{x}}\right)$, and the efficient land use index $\left(\mathrm{ELUI}_{\mathrm{x}}\right)$ for the growing of plants (p) and rearing of farm animals (a). $\mathrm{PDI}_{\mathrm{x}}$ shows the relation between numbers of crop species or number of animal species bred on a farm $\left(n_{\mathrm{sp}}\right)$ and the number of productive systems $\left(n_{\mathrm{s}}\right)$ for each farm $(i)$ within a zone with similar characteristics (equation 1). 
$\mathrm{PR}_{\mathrm{x}}$ identifies the potential risk factors that are derived from the number of constraints by physical and chemical soil characteristics ( $\left.n_{\mathrm{rf}}\right)$ with respect to the number of species of plants or animals $\left(n_{\mathrm{sp}}\right)$ for each production system $\left(n_{\mathrm{s}}\right)$ in each area (equation 2). ELUI assesses the efficiency of land use, relating $\mathrm{PDI}_{\mathrm{x}}$ and $\mathrm{PR}_{\mathrm{x}}$ in each production system from each community (equation 3 ):

$$
\begin{aligned}
& P D I_{x}=\sum_{i=1}^{n}\left[\frac{n_{s p}}{n_{s}}\right]_{i} \\
& P R_{x}=\sum_{i=1}^{n}\left[\left(\frac{n_{s}}{n_{s p}}\right)+n_{r f}\right]_{i} \\
& E L U I_{x}=\sum_{i=1}^{n}\left[\frac{I D P_{x}}{P R_{x}}\right]_{i}
\end{aligned}
$$

where $x$ represents the variable $(p)$ relating to plant cultivation and $(a)$ to rearing of farm animals, $n_{\mathrm{sp}}$ is the number of crop or animal species bred on a farm, $n_{\mathrm{s}}$ is the number of productive systems, $n_{\mathrm{rf}}$ is the number of potential constraints presented by soil physical and chemical characteristics, $n$ is the number of farms, and $i$ is the mean across the community. Dimensionless group values are interpreted as follows: the higher the numerical value, the greater the indicator, even though this depends on the kind of indicator. An increase in $\mathrm{PDI}_{\mathrm{x}}$ and $\mathrm{ELUI}_{\mathrm{x}}$ is considered favorable, whereas a higher value of PR would be unfavorable.

\section{Statistical analysis}

Each variable and index were analyzed using analysis of variance (ANOVA) comparisons of means by Tukey's test $(\mathrm{p} \leq 0.05)$; geochemical variables (OM, CEC, Ca, sand and TPH) and density of oil facilities were also examined through canonicalcorrelation analysis $(\mathrm{p} \leq 0.05)$ using Statgraphics Centurion XV (Statgraphics 2006). Finally, canonical correspondence analysis was conducted with $\mathrm{R}$ version 3.1.2 using "ca" (R Core Team 2014) to analyze the relationship between indices in zones with or without oil facilities.

\section{RESULTS}

\section{Agroecosystems and productive characterization}

All four study zones were characterized by vegetation that is typical of alluvial plains with flood conditions with productive problems due to the high humidity conditions. Productive use was represented by cultivated pastures (Echinochloa polystachya and
Brachiaria mutica) for feeding sheep. There was no observed agricultural use in remediated soil, which was characterized by mangroves (Laguncularia racemosa) and other species, such as Cyperus esculentus, Thalia geniculata and Mimosa pigra. In zones with moderate densities of oil wells (i.e., Paraiso and Ceiba), agricultural use was more evident with extensive cultivated pastures of Echinochloa polystachya and Brachiaria mutica for bovine livestock. Native species, such as Thalia geniculata, Mimosa pigra, Leucaena leucocephala, and Cyperus esculentus were also found. In Gurría, where there is no oil activity, a greater diversity of crops was noted, which included pastures of Paspalum distichum, subsistence crops (Zea mays and Phaseolus vulgaris), vegetable gardens (Cucumis sativus, Citrullus lanatus, and Cucurbita pepo), tropical fruit (Musa paradisiaca, Citrus aurantifolia Swingle, Cocos nucifera, and Manihot esculenta Crantz), and backyard livestock systems (poultry and farm animals); locals also engage in fishing activity. There were also areas with native vegetation, such as Thalia geniculata, Mimosa pigra, and other Mimosa spp. The main limiting factors were salinity and the typical conditions of low floodplains, with frequent flooding and Gleysols, therefore, Rovirosa soil is not suitable for agricultural production (Table I).

Salinity was extremely high in the soils that were located where there was a higher density of oil wells, and this was strongly correlated with TPH; we also observed sandy soil texture with very high content of $\mathrm{OM}$ and moderately high CEC. Petrogenic OM and high salt content in ecosystems that are susceptible to frequent flooding and poor drainage corresponded at least six risk factors for productive development. In addition, there was a lack of availability of soil nutrients. Finally, another indicator of soil disturbance was the excessive concentration of $\mathrm{Ca}$, which is not typical of these areas (Table II).

TPH concentrations differed significantly between communities $(\mathrm{p}<0.05)$, with a tendency to decrease with lower density of oil facilities (Table III). Soils contaminated with TPH were found in zones with a higher density of oil installations and were found to have values of 12276 to $3553 \mathrm{mg} / \mathrm{kg}$ of TPH. In zones with higher contamination, soil salinity was also higher in oil-contaminated soils $(56.8 \mathrm{dS} / \mathrm{m})$ than areas without oil installations $(2.4 \mathrm{dS} / \mathrm{m})$; and was found to be the most important limiting factor. The main limiting factors in areas with moderate density of oil facilities were TPH concentrations of $1000 \mathrm{mg} / \mathrm{kg}$, flooding zones, and moderate salinity (Table II). 
TABLE I. MAIN CHARACTERISTICS OF AGROECOSYSTEMS AND LAND USE PRODUCTION SYSTEMS IN STUDY AREAS.

\begin{tabular}{|c|c|c|c|c|c|}
\hline Zone & $\mathrm{OF}$ & Ecosystem description & Productive use & Production systems & Production risk factors \\
\hline Rovirosa & 14 & $\begin{array}{l}\text { Low jungle, meadow with } \\
\text { Echinochloa polystachya } \\
\text { (Kunth) Hitch, Brachiaria } \\
\text { mutica (Forssk.) Stapf } \\
\text { and flooded soils with } \\
\text { Laguncularia racemosa } \\
\text { (L.) C.F. Gaertn, Cype- } \\
\text { rus esculentus L., Thalia } \\
\text { geniculata L. and Mimosa } \\
\text { pigra } \text { L. with soil texture } \\
\text { disturbances }\end{array}$ & $\begin{array}{l}\text { Pasture grown on remedi- } \\
\text { ated soil. } \\
\text { Soil remediation process } \\
\text { without agricultural use }\end{array}$ & $\begin{array}{l}\text { Livestock (sheep) only in } \\
\text { remediated zones }\end{array}$ & $\begin{array}{l}\text { TPH, frequent flooding, } \\
\text { high salinity, petrogenic } \\
\text { OM content, higher per- } \\
\text { centage of sand, and low } \\
\text { levels of N, P, K }\end{array}$ \\
\hline Paraíso & 7 & $\begin{array}{l}\text { Low floodplain with } \\
\text { frequent flooding and } \\
\text { Gleysols. meadow } \\
\text { with Brachiaria mutica } \\
\text { (Forssk.) Stapf, Paspalum } \\
\text { distichum L., Leersia } \\
\text { hexandra Swartz, Thalia } \\
\text { geniculata L., Mimosa } \\
\text { pigra L., Leucaena leuco- } \\
\text { cephala L., and Cyperus } \\
\text { esculentus L. }\end{array}$ & Cultivated pasture & $\begin{array}{l}\text { Livestock (cattle) with } \\
\text { extensive grazing }\end{array}$ & $\begin{array}{l}\text { TPH, frequent flooding, } \\
\text { moderate salinity, petrogen- } \\
\text { ic OM content, and higher } \\
\text { percentage of clay }\end{array}$ \\
\hline Ceiba & 1 & $\begin{array}{l}\text { Low floodplain and mead- } \\
\text { ow with Echinochloa } \\
\text { polystachya, Paspalum } \\
\text { distichum L., Leersia } \\
\text { hexandra Swartz, Mimosa } \\
\text { pigra L., and Leucaena } \\
\text { leucocephala L. }\end{array}$ & Cultivated pasture & $\begin{array}{l}\text { Livestock (cattle) with } \\
\text { extensive grazing }\end{array}$ & $\begin{array}{l}\text { Frequent flooding, moder- } \\
\text { ate salinity, higher percent- } \\
\text { age of clay, and low level } \\
\text { of K }\end{array}$ \\
\hline Gurría & 0 & $\begin{array}{l}\text { Low jungle and floodplain } \\
\text { with frequent flooding and } \\
\text { Gleysols with Paspalum } \\
\text { distichum L., Panicum } \\
\text { máximum Jacq, Thalia ge- } \\
\text { niculata L., Mimosa pigra } \\
\text { L. and Mimosa pudica L. }\end{array}$ & $\begin{array}{l}\text { Native and cultivated pas- } \\
\text { ture. Subsistence crops }\end{array}$ & $\begin{array}{l}\text { Subsistence agriculture } \\
\text { with basic crops (corn, } \\
\text { beans), vegetables } \\
\text { (cucumber, watermelon, } \\
\text { pumpkin), fruit (banana, } \\
\text { lemon), coconut and cas- } \\
\text { sava. } \\
\text { Subsistence livestock } \\
\text { (poultry and farm ani- } \\
\text { mals) }\end{array}$ & $\begin{array}{l}\text { Frequent flooding, salinity, } \\
\text { higher percentage of clay, } \\
\text { and low level of } \mathrm{K}\end{array}$ \\
\hline Gurría & 0 & $\begin{array}{l}\text { Low jungle and floodplain } \\
\text { with frequent flooding and } \\
\text { Gleysols with Paspalum } \\
\text { distichum L., Panicum } \\
\text { máximum Jacq, Thalia ge- } \\
\text { niculata L., Mimosa pigra } \\
\text { L. and Mimosa pudica L. }\end{array}$ & $\begin{array}{l}\text { Native and cultivated pas- } \\
\text { ture. Subsistence crops }\end{array}$ & $\begin{array}{l}\text { Subsistence agriculture } \\
\text { with basic crops (corn, } \\
\text { beans), vegetables } \\
\text { (cucumber, watermelon, } \\
\text { pumpkin), fruit (banana, } \\
\text { lemon), coconut and cas- } \\
\text { sava. } \\
\text { Subsistence livestock } \\
\text { (poultry and farm ani- } \\
\text { mals) }\end{array}$ & $\begin{array}{l}\text { Frequent flooding, salinity, } \\
\text { higher percentage of clay, } \\
\text { and low level of } \mathrm{K}\end{array}$ \\
\hline
\end{tabular}

OF: density of oil wells over $100 \mathrm{~m}^{2}$. TPH: total petroleum hydrocarbons. OM: organic matter.

\section{Risk analysis of limiting factors \\ Canonical correlation analysis indicated that the greatest diversity and production efficiency}

was found in Gurría (no oil installations), while highest risks were found in sites with greater density of oil installations (Rovirosa > Paraíso > 


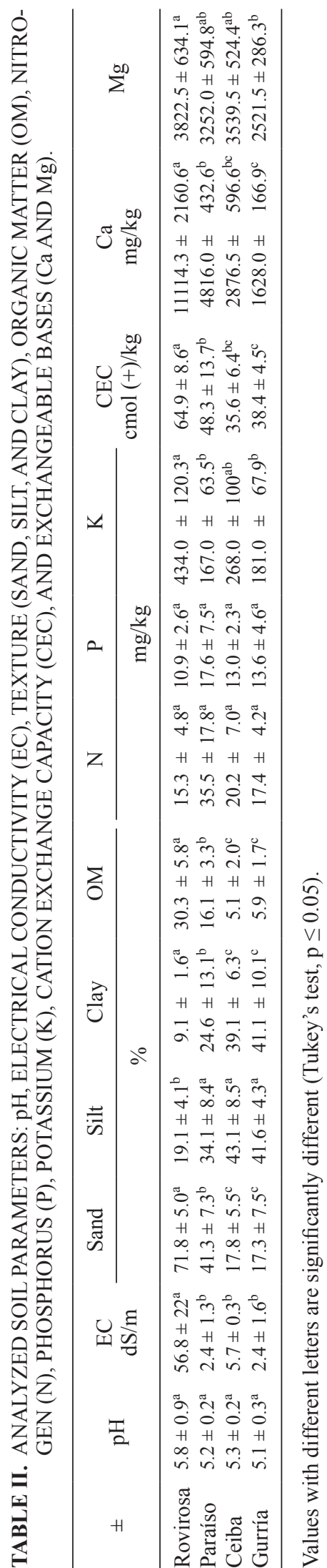

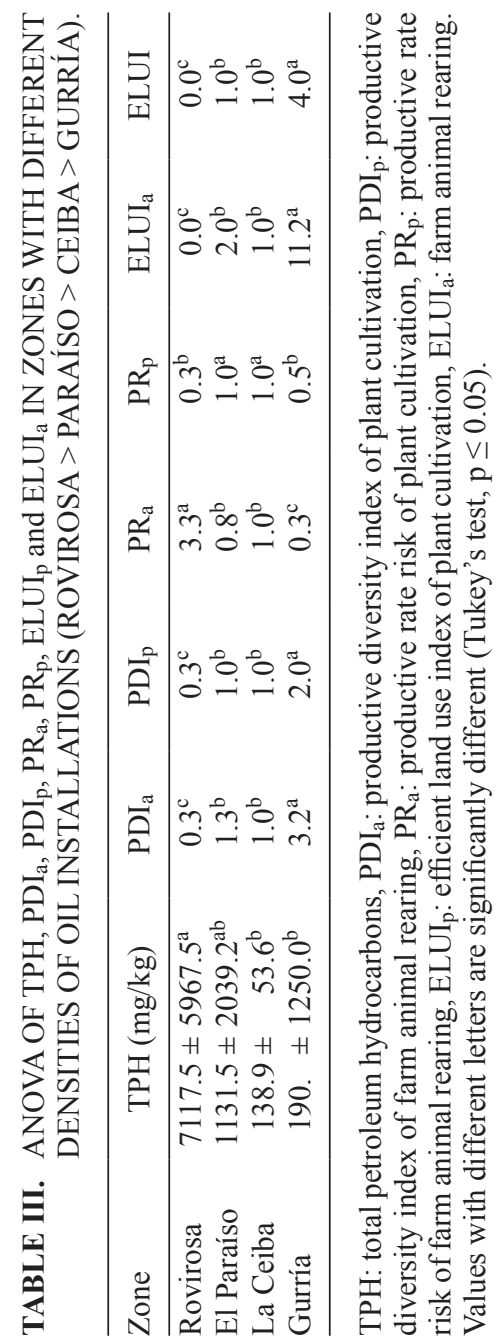

Ceiba) (Fig. 2). In Gurría, the value of $\mathrm{RP}_{\mathrm{p}, \mathrm{a}}$ was lower, with higher PDI p,a $_{\text {a }}$ and IES $\mathrm{p}_{\mathrm{p}, \mathrm{a}}$ values; this was due to the greater diversity of crops and pastures (Table II).

Canonical correlation analysis with respect to analyzed soil geochemical variables (OM, CEC, Ca, Sand and TPH) indicated a high significant relationship $(\mathrm{p}<0.01)$, explaining the increase of $\mathrm{PR}_{\mathrm{p}, \mathrm{a}}$ in the presence of greater density of petroleum facilities (Fig. 3). The negative correlation between soil geochemical variables (OM, CEC, Ca, Sand and TPH) with respect to $E L U I_{p, a}$ and $P_{p D}$ let to identify the risk factors associated with productive development in contaminated areas, as describe above in table II.

Indicators of potential risk assessment

Correspondence analysis indicated that the greatest diversity and production efficiency was found in Gurría (no oil installations), whereas the highest risks 


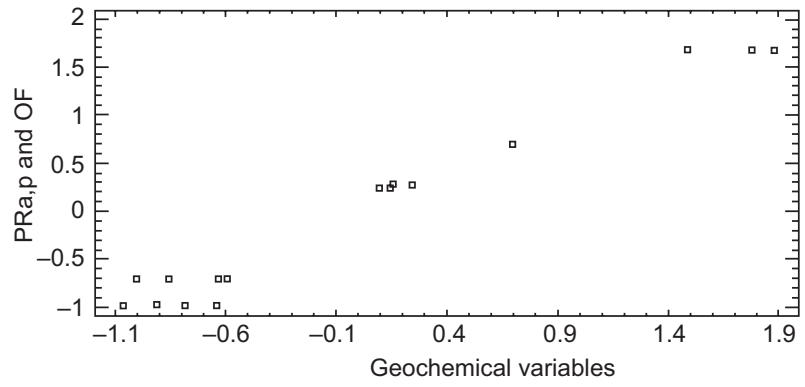

Fig. 2. Canonical correlation analysis between geochemical variables: organic matter $(\mathrm{OM})$, cation exchange capacity (CEC), sand, exchangeable cation (Ca), total petroleum hydrocarbons (TPH) and the productive rate risk of plant cultivation $\left(\mathrm{PR}_{\mathrm{a}}\right)$, the productive rate risk of farm animal rearing $\left(\mathrm{PR}_{\mathrm{p}}\right)$ and density of oil facilities $(\mathrm{OF})(\mathrm{p}<0.01)$.

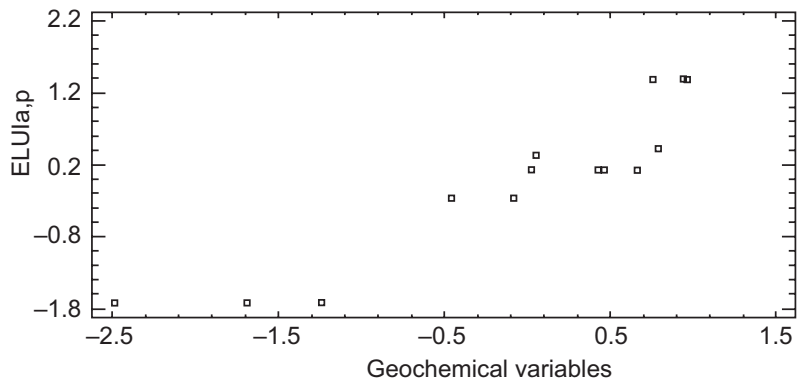

Fig. 3. Canonical correlation analysis between geochemical variables: organic matter $(\mathrm{OM})$, cation exchange capacity (CEC), sand, exchangeable cation (Ca), total petroleum hydrocarbons (TPH) with respect to efficient land use index of plant $\left(E L U I_{p}\right)$ and farm animals $\left(E_{L U I}\right)(p<$ $0.01)$.

were found in the zones with greater density of oil installations (Rovirosa $>$ Paraíso $>$ Ceiba) (Fig. 4). In Gurría, the value of $\mathrm{RP}_{\mathrm{p}, \mathrm{a}}$ was lower, with higher $\mathrm{PDI}_{\mathrm{p}, \mathrm{a}}$ and $\mathrm{IES}_{\mathrm{p}, \mathrm{a}}$ values, which was due to the greater diversity of crops and pastures.

\section{DISCUSSION}

Agroecosystems and productive characterization Monitoring in agricultural areas adjacent to petroleum facilities allows the environmental authorities to consider and focus efforts on fertility based in agroecological characteristics and land use, on which subsistence smallholders of developing countries depend (Vignola et al. 2015). In the Ecuadorian Amazon, petroleum hydrocarbons have been found in the hunting and fishing areas, endangering wildlife and indigenous populations in the region,

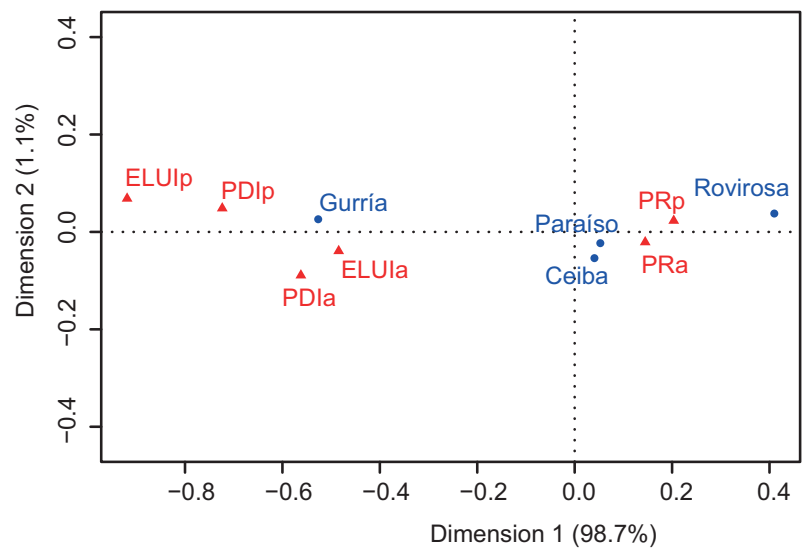

Fig. 4. Correspondence analysis by indices: $\mathrm{PDI}_{\mathrm{a}}$ is the productive diversity index of plant cultivation, $\mathrm{PDI}_{\mathrm{p}}$ is the productive diversity index of farm animal rearing, $\mathrm{PR}_{\mathrm{a}}$ is the productive rate risk of plant cultivation, $P_{p}$ is the productive rate risk of farm animal rearing, ELUI is the efficient land use index of plant cultivation and ELUI is the efficient land use index of farm animal rearing in zones with different densities of oil installations (Rovirosa $>$ Paraíso $>$ Ceiba $>$ Gurría)

because they are exposed to the ingestion of soils and sediments contaminated with oil (Rosell-Melé et al. 2018). This form of translocation of the contaminants is also a risk to agriculture, for example, in the rhizosphere of reeds, n-alkanes have been found in the range of $\mathrm{C} 10$ to $\mathrm{C} 33$ in the upper layers of the soil (10 $\mathrm{cm}$ depth of soil), through irrigation with irrigation water from the river (Tian et al. 2014).

Gleysol is mostly used for the cultivation of grasses (Saggar et al. 2001). In this case grasslands with Brachiaria brizantha (Hochst) Stapf and crops such as Zea mays L. are more tolerant to the presence of petroleum derivatives, while legumes like Neonotonia wightii Arn. can be severely affected (Gürtler et al. 2018), which would explain the presence of halophilic plants and grasses in the study area.

In this study, the presence of pastures in contaminated soils is due to their high resilience to toxic effects of TPH (Franco et al. 2004) and their tolerance to constant flooding and lack of drainage from these areas, which represents a risk for the present vegetation (Sims and Colloff 2012). In this case, the pollutant can be dissipated by water during the six months that the soil remains flooded. Zones contaminated with oil were characterized by plants belonging to the families Poaceae, Cyperaceae, and Fabaceae (García-López et al. 2006), which coincides with the data reported in this study. Echinochloa polystachya and Brachiaria mutica are perennial grass found in oil-polluted soils that contain high concentrations of 
petroleum, heavy metals and salts (Solís-Domínguez et al. 2007, Panta et al. 2014, Fatima et al. 2016). Laguncularia racemosa is a mangrove species found in this study, which has been reported with reductions in growth rates of up to $20 \%$ in response to a simulated oil spill of $5 \mathrm{~L} / \mathrm{m}^{2}$ (Sodré et al. 2013), and in conditions of high salinity the efficiency of the plant in the use of nitrogen decreases between 37 and $58 \%$ (Sobrado 2005).

\section{Risk analysis of limiting factors}

The soil in this area has been reported as Mollic Gleysol (Rivera-Cruz et al. 2005), typical of alluvial plains and characterized by rich OM, high nutrient content, and clayey, silty texture (IUSS Working Group WRB 2006). But, in this study, it was found that there was a higher sand content in the transition zone of the floodplain that coincided with the oil spill in Rovirosa: an area that contains fine deposits and terrace sediments of shale and sandstone. The density of oil wells was high (equidistance of $380 \mathrm{~m}$ ), and these were constructed with materials from fill terraces which had eroded and accumulated on the Gleysol. There have also been clean-ups of material accumulated underground, with removal of sandy materials ex situ, resulting in disturbances to soil texture.

Gutiérrez and Zavala (2002) indicated that the typical nature of these Gleysols allows for the accumulation of hydrocarbons in the groundmass, in which case, it contains a few active surfaces that promote efficient drainage and extend the leaching toxicity of oil. Mikkonen et al. (2012) found that the vertical gradient of the proportion of aliphatic and aromatic hydrocarbons increased with the depth of the soil profile, and it is, therefore, important to consider pollutant transport in the ground profile and the potential for groundwater contamination. Should this occur, surface water wells, aquatic organisms, and the food chain could be severely affected (Perhar and Arhonditsis 2014). Such situations can be aggravated by the fact that the oil originates from past spills, with petroleum that has been weathered having high molecular weight compounds (Vega et al. 2009). As a result, soils have suffered physical degradation; and the quality and sustainability of their chemical (Gallego et al. 2010), biological, and enzymatic processes (Alrumman et al. 2015) have been jeopardized. Petroleum hydrocarbon contamination is, therefore, a major constraint to agricultural production and may represent a risk to human health due to the possibility of direct contact with contaminated soil (Zhao et al. 2014), also, something that was not studied in this research was the bioaccumulation of trace elements ( $\mathrm{As}, \mathrm{Cd}, \mathrm{Co}, \mathrm{Cr}, \mathrm{Cu}, \mathrm{Pb}$ and $\mathrm{Zn}$ ) in native plants (Robichaud et al. 2019), animals and sediments (Li et al. 2019), which should be analyzed in subsequent investigations.

Moreover, although OM in soil is usually a good indicator of fertility, in these soils the higher OM does not mean an improvement in soil quality, due to the ratios of $\mathrm{C} / \mathrm{N}$ and $\mathrm{C} / \mathrm{P}$ being unfavorable for microbial growth and enzymatic activity (Gao et al. 2013). Zavala-Cruz et al. (2005) found that high OM content in Gleysol also retains TPH fractions and may alter the solubility of phosphorus. Studies have suggested that an increase in organic waste decomposition can reduce the concentration of hydrocarbons and stimulate soil microbiota (Martín-Gil et al.2008). In a study conducted in China, no correlation was observed between the OM content and the individual or total polycyclic aromatic hydrocarbons (PAHs) concentrations, and no significant relationships were found between the $\mathrm{pH}$ or total nitrogen. In this study, the zones were mainly located in agricultural regions where the artificial introduction of organic fertilizers may affect the fate of PAHs (Liu et al. 2016).

Some authors note that CEC is not affected by oil in the ground (Martínez and López 2001); however, EC can measure the salinity of soil extracts. The soil salinity is crucial to the survival of many plant species because salinity has effects on the osmotic potential of plants, with high salinity causing loss of intracellular water, reducing swelling, and increasing the accumulation of ions (sodium and chloride); this may directly interfere with internal biochemical processes. Effects range from limiting processes of germination and plant growth to posing a risk to animal feed (Masters et al. 2007). In this study, the severe salinity of the samples that were found near petrochemical facilities was probably due to water associated with extraction and storage processes, which generally have a high content of dissolved salt from geological formations (salt domes) (van Thienen-Visser et al. 2014); this reduces the potential for agricultural production. De la Garza et al. (2008) suggested that in soils with higher hydrocarbon concentrations, $\mathrm{pH}$ decreases but EC increases 5.6 times compared to uncontaminated soil, reducing the ability to retain $\mathrm{Ca}$ and $\mathrm{K}$ cations.

A limiting factor for agricultural production was the very high content of TPH, since $1.5 \%$ represents a critical value for plant growth (Tang et al. 2011). High soil salinity has also been one of the main problems in contaminated soil because of negative synergistic effects on soil bacterial diversity (Gao et al. 2015). Furthermore, the specific characteristics of these soils in relation to flooding and excessive salinity 
levels can affect plant growth and development, affecting natural attenuation of petroleum (Tang et al. 2012), due to a reduction in cellulose decomposition. Furthermore, fertility problems arising from having chemical properties outside acceptable parameters limit availability of some nutrients $(\mathrm{P}$ and $\mathrm{N})$ and pose a danger of oversupply of others $(\mathrm{Na})$, increasing risks to both plant and animal production; however, there are plants such as the white mangrove, which has been characterized as a plant that can tolerate these conditions (Kathiresan and Bingham 2001).

\section{Indicators of potential risk assessment}

The improper handling of refined petroleum products are potential sources of soil contamination that have been documented (Yamprai et al. 2014), and thus we propose indicators as simple assessments of risk factors in situ, based on analyses of information about the type of crops that have been cultivated by farmers. Land use planning and policy decisionmaking are crucial to avoid conflicts between the government and the local people (Duangjai et al. 2015); typical problems that have been reported in oil zones (Acuña 2015).

The productive characterization led to identifying the ecosystem in order to recognize the limiting factors from the natural and the anthropogenic conditions. In this case, flood characteristics were typical of lowland jungle, and there are even previous studies that have evaluated the zone type and its potential for ecosystem services (Namaalwa et al. 2013). The indicators recommended in this study allow productive diversity to be integrated as one of the many soil functions, providing criteria that demonstrate the deterioration in soil quality (Rodríguez and Lafarga 2011). The inclusion of more indicators, however, could assist in developing a more comprehensive view of soil functioning (Schloter et al. 2003), which will certainly have an impact on sustainable agricultural development (Volchko et al. 2013). Thus, concentrations between 250.49 and $9387.26 \mathrm{ng} / \mathrm{g}$ of PAH have been found in agricultural lands in China, representing more than 60 $\%$ of all PAHs (Liu et al. 2016).

Goodsir et al. (2019) indicate that the criteria for risk assessment of pollutants must include aspects of ecological sensitivity and socioeconomic receptors to finally decide if a remediation, intervention or monitoring program is required. Other authors have developed a multivariable index, which includes all individual compounds, based on toxicological studies (PAH and BTEX) compared with TPH, which allows simplifying the soil evaluation by reducing the number of variables (Pinedo et al. 2013). Therefore, recent studies suggest the development of evaluation methods and systems that involve the monitoring of ecotoxicity and the detection of in situ bioindicators (Shen et al. 2016), so the indicators of the present study could be a reference for the attention of sites contaminated by petroleum hydrocarbons.

\section{CONCLUSION}

The results of the present study indicate that elevated concentrations of TPH, extremely high salinity, petrogenic OM, and a high percentage of sand are the main risk factors in contaminated soil with low levels of N, P, and K. Frequent flooding also serves as a potential risk to agricultural production. Furthermore, the density of oil facilities was positively correlated with the index of productive risk $\left(\mathrm{PR}_{\mathrm{p}, \mathrm{a}}\right)$, whereas a greater diversity and productive efficiency were found in areas with lower density of oil wells. These results enabled a comparison to be made of risk factors on land use potential in areas with similar ecosystems, but with differences between productive diversity and density of oil installations.

PDI, PR, and ELUI for farming systems were shown to be indicators for a simple assessment of risk factors in situ based on analyzing physical and chemical soil characteristics, the concentrations of hydrocarbons and the productive characterization. The use of these indicators can help decision makers recognize the limiting factors of flood characteristics typical of low jungle areas, with and without oil facilities, and is particularly useful for monitoring environmental authorities in agriculture areas close to oil installations.

\section{ACKNOWLEDGMENTS}

We thank Dr. Macario Vázquez Rivera and Irma Luna Capetillo for their valuable support, the Technical Council of Colegio de Postgraduados and Dr. Dolores Castañeda Antonio for scientific consultancy services. We are also grateful to CONACyT-57345 and the Universidad Veracruzana for financing the publication of this article.

\section{REFERENCES}

Acuña R.M. (2015). The politics of extractive governance: Indigenous peoples and socio-environmental conflicts. Extr. Ind. Soc. 2, 85-92. https://doi.org/10.1016/j. exis.2014.11.007 
Adams H.R., Guzmán O.F. and Zavala C.J. 2008. Water repellency in oil contaminated sandy and clayey soils. Int. J. Environ. Sci. Tech. 5 (4), 445-454. https://doi. org/10.1007/BF03326040

Alrumman S.A., Standing D.B. and Paton G.I. (2015). Effects of hydrocarbon contamination on soil microbial community and enzyme activity. J. King Saud Univ.-Sci. 27, 31-41. https://doi.org/10.1016/j. jksus.2014.10.001

Cuevas-Díaz M.D.C., Vázquez-Luna D., MartínezHernández S., Guzmán-López O. and Ortiz-Ceballos A.I. (2017). Sensitivity of the endogenic tropical earthworm Pontoscolex corethrurus to the presence of heavy crude oil. Bull. Environ. Contam. Toxicol. 99, 154-160. https://doi.org/10.1007/s00128-017-2126-2

Duangjai W., Schmidt-Vogt D. and Shrestha R.P. (2015). Farmers' land use decision-making in the context of changing land and conservation policies: A case study of Doi Mae Salong in Chiang Rai Province, Northern Thailand. Land Use Policy 48, 179-189. https://doi. org/10.1016/j.landusepol.2015.06.002

De la Garza E.R., Ortiz Y.P., Macias B.A., García C. and Coll D. (2008). Actividad biótica del suelo y la contaminación por hidrocarburos. Revista Latinoamericana de Recursos Naturales 4 (2), 49-54.

EPA (1986). Method 418.1 mod. Petroleum hydrocarbons. Environmental Protection Agency. Washington, D.C., $38 \mathrm{pp}$.

Fatima K., Imran A., Amin I., Khan Q. M. and Afzal M. (2016). Plant species affect colonization patterns and metabolic activity of associated endophytes during phytoremediation of crude oil-contaminated soil. Environ. Sci. Pollut. Res. 23 (7), 6188-6196. https://doi. org/10.1007/s11356-015-5845-0

Fernández M.D., Vega M.M. and Tarazona J.V. (2006). Risk-based ecological soil quality criteria for the characterization of contaminated soils. Combination of chemical and biological tools. Sci. Total Environ. 366 (2), 466-484. https://doi.org/10.1016/j.scitotenv.2006.01.013

Franco I., Contin M., Bragato G. and De Nobili M. (2004). Microbiological resilience of soils contaminated with crude oil. Geoderma 121, 17-30. https://doi. org/10.1016/j.geoderma.2003.10.002

Gallego J.R., Sierra C., Villa R., Peláez A.I. and Sánchez J. (2010). Weathering processes only partially limit the potential for bioremediation of hydrocarbon-contaminated soils. Org. Geochem. 41, 896-900. https://doi. org/10.1016/j.orggeochem.2010.04.021

Gao Y.-C., Wang J.-n., Xu J.-b., Kong X., Zhao L. and Zeng D.-H. (2013). Assessing the quality of oil-contaminated saline soil using two composite indices. Ecol. Indic. 24, 105-113. https://doi.org/10.1016/j.ecolind.2012.06.005
Gao Y.-C., Wang J.-N., Guo S.-H., Hu Y.-L., Li T.-T., Mao R. and Zeng D.-H. (2015). Effects of salinization and crude oil contamination on soil bacterial community structure in the Yellow River Delta region, China. Appl. Soil Ecol. 86, 165-173. https://doi.org/10.1016/j. apsoil.2014.10.011

García-López E., Zavala-Cruz J. and Palma-López D.J. (2006). Characterization of plant communities in an area affected by hydrocarbon spills. Terra Latinoamericana $24,17-26$.

Goodsir F., Lonsdale J.A., Mitchell P.J., Suehring R., Farcas A., Whomersley P., Brant J.L., Clarke C., Kirby M.F., Skelhorn M. and Hill P.G. (2019). A standardised approach to the environmental risk assessment of potentially polluting wrecks. Mar. Pollut. Bull. 142, 290302. https://doi.org/10.1016/j.marpolbul.2019.03.038

Gürtler S., Souza-Filho C.R., Sanches I.D., Alves M.N. and Oliveira W.J. (2018). Determination of changes in leaf and canopy spectra of plants grown in soils contaminated with petroleum hydrocarbons. ISPRS J. Photogramm. 146, 272-288. https://doi.org/10.1016/j. isprsjprs.2018.09.011

Gutiérrez M.C. and Zavala C.J. (2002). Hydromorphic pedofeatures in hydrocarbon polluted tropical soils. Terra Latinoamericana 20, 101-111.

Hall C., Tharakan P., Hallock J., Cleveland C. and Jefferson M. (2003). Hydrocarbons and the evolution of human culture. Nature 426, 318-322. https://doi. org/10.1038/nature02130

IUSS Working Group WRB (2006). World reference base for soil resources 2006. A framework for international classification, correlation and communication. 2nd ed. World soil resources reports No. 103. International Union of Soil Sciences (IUSS), Food and Agriculture Organization of the United Nations, Rome, Italy, 145 pp.

Kathiresan K. and Bingham B. (2001). Biology of mangroves and mangrove ecosystems. Adv. Mar. Biol. 40, 81-251. https://doi.org/10.1016/S00652881(01)40003-4

Labud V., García C. and Hernández T. (2007). Effect of hydrocarbon pollution on the microbial properties of a sandy and a clay soil. Chemosphere 66 (10), 1863-1871. https://doi.org/10.1016/j.chemosphere.2006.08.021

Li C., Yang L., Shi M. and Liu G. (2019). Persistent organic pollutants in typical lake ecosystems. Ecotoxicol. Environ. Saf. 180, 668-678. https://doi.org/10.1016/j. ecoenv.2019.05.060

Liu G., Niu J., Guo W., An X. and Zhao L. (2016). Ecological and health risk-based characterization of agricultural soils contaminated with polycyclic aromatic hydrocarbons in the vicinity of a chemical plant in China. Chemosphere 163, 461-470. https:// doi.org/10.1016/j.chemosphere.2016.08.056 
Martín-Gil J., Navas-Gracia L., Gómez-Sobrino E., Correa-Guimaraes A., Hernández-Navarro S., Sánchez-Báscones M. and Ramos-Sánchez M.C. (2008). Composting and vermicomposting experiences in the treatment and bioconversion of asphaltens from the Prestige oil spill. Bioresour. Technol. 99 (6), 18211829. https://doi.org/10.1016/j.biortech.2007.03.031

Martínez E.M. and López F.S. (2001). Effects of hydrocarbon pollutants on the physical and chemical properties of clay soil. Terra Latinoamericana 19, 9-17.

Masters D.G., Benes S.E. and Norman H.C. (2007). Biosaline agriculture for forage and livestock production. Agric., Ecosyst. Environ. 119, 234-248. https://doi. org/10.1016/j.agee.2006.08.003

Mikkonen A., Hakala K.P., Lappi K., Kondo E., Vaalama A. and Suominen L. (2012). Changes in hydrocarbon groups, soil ecotoxicity and microbiology along horizontal and vertical contamination gradients in an old landfarming field for oil refinery waste. Environ. Pollut. 162, 374-380. https://doi.org/10.1016/j.envpol.2011.12.012

Namaalwa S., Van dam A.A., Funk A., Ajie G.S. and Kaggwa R.C. 2013. A characterization of the drivers, pressures, ecosystem functions and services of Namatala Wetland, Uganda. Environmental Science \& Policy 34: 44-57. https://doi.org/10.1016/j.envsci.2013.01.002

Panta S., Flowers T., Lane P., Doyle R., Haros G. and Shabala S. (2014). Halophyte agriculture: Success stories. Environ. Exp. Bot. 107, 71-83. https://doi. org/10.1016/j.envexpbot.2014.05.006

Pinedo J., Ibáñez R., Lijzen J.P.A. and Irabien Á. (2013). Assessment of soil pollution based on total petroleum hydrocarbons and individual oil substances. J. Environ. Manage. 130, 72-79. https://doi.org/10.1016/j.jenvman.2013.08.048

Perhar G. and Arhonditsis G. (2014). Aquatic ecosystem dynamics following petroleum hydrocarbon perturbations: A review of the current state of knowledge. J. Great Lakes Res. 40, 56-72. https://doi.org/10.1016/j. jglr.2014.05.013

$\mathrm{R}$ Core Team (2014). R: A language and environment for statistical computing. R Foundation for Statistical Computing.

Rivera-Cruz M.C. y Trujillo-Narcia A. (2004). Estudio de toxicidad vegetal en suelos con petróleos nuevo e intemperizado. Interciencia 29, 369-376.

Rivera-Cruz M.C., Trujillo-Narcía A., Miranda C.M. y Maldonado C.E. (2005). Evaluación toxicológica de suelos contaminados con petróleos nuevo e intemperizado mediante ensayos conleguminosas. Interciencia 30, 326-331.

Robichaud K., Stewart K., Labrecque M., Hijri M., Cherewyk J. and Amyot M. (2019). An ecological microsystem to treat waste oil contaminated soil: Using phytoremediation assisted by fungi and local compost, on a mixed-contaminant site, in a cold climate. Sci. Total Environ. 672, 732-742. https://doi.org/10.1016/j. scitotenv.2019.03.447

Rodrigues S.M., Pereira M.E., Ferreira D.A., Silva E., Hursthouse A.S. and Duarte A.C. (2009). A review of regulatory decisions for environmental protection: Part I Challenges in the implementation of national soil policies. Environ. Int. 35, 202-213. https://doi. org/10.1016/j.envint.2008.08.007

Rodríguez M. and Lafarga J. (2011). Soil quality criteria for environmental pollutants. Reference module in earth systems and environmental Sciences. In: Encyclopedia of environmental health (Nriagu J.O., Ed.). Elsevier, Burlington, EUA, 124-142. https://doi. org/10.1016/B978-0-444-52272-6.00632-2

Rosell-Melé A., Moraleda-Cibrián N., Cartró-Sabaté M., Colomer-Ventura F., Mayor P. and Orta-Martínez M. (2018). Oil pollution in soils and sediments from the northern peruvian amazon. Science of The Total Environment 610-611: 1010-1019. https://doi. org/10.1016/j.scitotenv.2017.07.208

Saggar S., Yeates G.W. and Shepherd T.G. (2001). Cultivation effects on soil biological properties, microfauna and organic matter dynamics in Eutric Gleysol and Gleyic Luvisol soils in New Zealand. Soil Tillage Res. 58 (1), 55-68. https://doi.org/10.1016/S01671987(00)00184-7

Schloter M., Dilly O. and Munch J. (2003). Indicators for evaluating soil quality. Agric. Ecosyst. Environ. 98 (1-3), 255-262. https://doi.org/10.1016/S01678809(03)00085-9

SEMARNAT (2002). Norma Oficial Mexicana NOM021-RECNAT-2000. Que establece las especificaciones de fertilidad, salinidad y clasificación, estudio, muestreo y análisis de suelos. Diario Oficial de la Federación, México, 31 de diciembre.

SEMARNAT (2005). NOM-138-SEMARNAT/SS-2003. Norma Oficial Mexicana que establece los límites máximos permisibles de hidrocarburos en los suelos y las especificaciones para su caracterización y remediación. Diario Oficial de la Federación, México, 29 de marzo.

Sims N.C. and Colloff M.J. (2012). Remote sensing of vegetation responses to flooding of a semi-arid floodplain: Implications for monitoring ecological effects of environmental flows. Ecol. Indic. 18, 387-391. https:// doi.org/10.1016/j.ecolind.2011.12.007

Shen W., Zhu N., Cui J., Wang H., Dang Z., Wu P., Luo Y. and Shi C. (2016). Ecotoxicity monitoring and bioindicator screening of oil-contaminated soil during bioremediation. Ecotoxicol. Environ. Saf. 124, 120-128. https://doi.org/10.1016/j.ecoenv.2015.10.005 
Sobrado M.A. (2005). Leaf characteristics and gas exchange of the mangrove Laguncularia racemosa as affected by salinity. Photosynthetica 43 (2), 217-221. https://doi.org/10.1007/s11099-005-0036-8

Sodré V., Caetano V.S., Rocha R.M., Carmo F.L., Medici L.O., Peixoto R.S., Rosado A.S. and Reinert F. (2013). Physiological aspects of mangrove (Laguncularia racemosa) grown in microcosms with oil-degrading bacteria and oil contaminated sediment. Environ. Pollut. 172, 243-249. https://doi.org/10.1016/j.envpol.2012.09.003

Solís-Domínguez F.A., González-Chávez M.C., CarrilloGonzález R. and Rodríguez-Vázquez R. (2007). Accumulation and localization of cadmium in Echinochloa polystachya grown within a hydroponic system. J. Hazard. Mater. 141 (3), 630-636. https://doi.org/10.1016/j. jhazmat.2006.07.014

Statgraphics (2006). Statgraphics Centurion XV User Manual. StatPoint, USA.

Tang J., Wang M., Wang F., Sun Q. and Zhou Q.X. (2011). Eco-toxicity of petroleum hydrocarbon contaminated soil. J. Environ. Sci. 23 (5), 845-51. https://doi. org/10.1016/S1001-0742(10)60517-7

Tang J., Lu X., Sun Q. and Zhu W. (2012). Aging effect of petroleum hydrocarbons in soil under different attenuation conditions. Agric. Ecosyst. Environ. 149, 109-117. https://doi.org/10.1016/j.agee.2011.12.020

Thavamani P., Smith E., Kavitha R., Mathieson G., Megharaj M., Srivastava P. and Naidu R. (2015). Risk based land management requires focus beyond the target contaminants. A case study involving weathered hydrocarbon contaminated soils. Environ. Technol. Innovation 4, 98-109. https://doi.org/10.1016/j. eti.2015.04.005

Teng Y., Wu J., Lu S., Wang Y., Jiao X. and Song L. (2014). Soil and soil environmental quality monitoring in China: A review. Environ. Int. 69, 177-199. https:// doi.org/10.1016/j.envint.2014.04.014

Tian W., Zhao Y., Sun H., Bai J., Wang Y. and Wu C. (2014). The effect of irrigation with oil-polluted water on microbial communities in estuarine reed rhizosphere soils. Ecol. Eng. 70, 275-281. https://doi.org/10.1016/j. ecoleng.2014.06.003
Van Thienen-Visser K., Hendriks D., Marsman A., Nepveu M., Groenenberg R., Wildenborg T., Duijne H.V., Hartogh M.D. and Pinkse T. (2014). Bow-tie risk assessment combining causes and effects applied to gas oil storage in an abandoned salt cavern. Eng. Geol. 168, 149-166. https://doi.org/10.1016/j.enggeo.2013.11.002

Vega A.F., Covelo F.E., Reigosa J.M. and Andrade M.L. (2009). Degradation of fuel oil in salt marsh soils affected by the Prestige oil spill. J. Hazard. Mater. 166, 10201029. https://doi.org/10.1016/j.jhazmat.2008.11.113

Vignola R., Harvey C.A., Bautista-Solís P., Avelino J., Rapidel B., Donatti C. and Martínez R. (2015). Ecosystem-based adaptation for smallholder farmers: Definitions, opportunities and constraints. Agric. Ecosyst. Environ. 211, 126-132. https://doi.org/10.1016/j. agee.2015.05.013

Volchko Y., Norrman J., Bergknut M., Rosén L. and Söderqvist T. (2013). Incorporating the soil function concept into sustainability appraisal of remediation alternatives. J. Environ. Manage. 129, 367-376. https:// doi.org/10.1016/j.jenvman.2013.07.025

Yan L., Penttinen P., Simojoki A., Stoddard F.L. and Lindström K. (2015). Perennial crop growth in oilcontaminated soil in a boreal climate. Sci. Total Environ. 532, 752-761. https://doi.org/10.1016/j. scitotenv.2015.06.052

Yamprai A., Mala T. and Sinma K. (2014). The study on the fixed nitrogen and nitrogenase activity in the day-round of Azotobacter and Azosprillum grown with maize in Kamphaeng Saen soil series. Mod. Appl. Sci. 8, 1-27 https://doi.org/10.5539/mas.v8n6p27

Zavala-Cruz J., Gavi-Reyes F., Adams-Schroeder R.H., Ferrera-Cerrato R., Palma-López D.J. and VaqueraHuerta H. (2005). Oil spills on soils and adaptation of tropical grass in Activo Cinco Presidentes, Tabasco, Mexico. Terra Latinoamericana 23, 293-302.

Zhao L., Hou H., Shangguan Y., Cheng B., Xu Y., Zhao R., Zhang Y., Hua X., Huo X. and Zhao X. (2014). Occurrence, sources, and potential human health risks of polycyclic aromatic hydrocarbons in agricultural soils of the coal production area surrounding Xinzhou, China. Ecotoxicol. Environ. Saf. 108, 120-128. https:// doi.org/10.1016/j.ecoenv.2014.05.034 